\title{
LINIERISASI THERMISTOR NTC MENGGUNAKAN METODA PENGUAT INVERTING
}

\author{
Wahyu Budi Mursanto \\ Jurusan Teknik Konversi Energi - Politeknik Negeri Bandung \\ email :wahyupoli@yahoo.com
}

\begin{abstract}
Abstrak
Penelitian ini menggunakan sensor thermistor yang memiliki koefisien negatif atau NTC ( Negatif Temperature Coefficien). Thermistor ini memiliki karakteristik yang tidak linier. Dengan karakteristik yang tidak linier tersebut, maka dilakukan metode linierisasi menggunakan metoda penguat inverting. Alat Ukur temperatur ini diaplikasikan pada sistem water heater yang memiliki batas pengukuran dari $15^{\circ}$ hingga $75^{\circ} \mathrm{C}$. Alat ukur ini membutuhkan sebuah rangkaian pengkondisi sinyal agar tegangan keluarannya pada 0 Volt hingga 5 Volt yag nantinya akan dibaca oleh ADC untuk ditampilkan pada layar monitor PC atau LCD display.

Hasil pengujian menunjukkan bahwa penentuan resistor linierisasi " $r$ " sebesar 3140 Ohm mampu membuat alat ukur menjadi linier (nilai $R^{2}=0,99909$ ). Alat ukur temperatur yang dibuat mampu memberikan hasil pembacaan temperatur dengan tingkat kesalahan $\pm 1^{\circ} \mathrm{C}$.
\end{abstract}

Kata kunci :Thermistor, NTC, linierisasi, pengkondisi sinyal.

\section{Daftar Simbol :}

$T$ : Temperatur, ${ }^{\circ} \mathrm{C}$.

$V$ : Tegangan, $V$ (Volt).

$R$ : Tahanan, $\Omega(\mathrm{Ohm})$.

$\beta$ : Konstanta material thermistor $\left({ }^{\circ} \mathrm{K}\right)$.

\section{PENDAHULUAN}

Dari sekian banyak variabel proses yang ada dalam dunia industri, didominasi oleh variabel dasar berupa temperatur, flow, pressure dan level [1]. Dari kempat variabel proses dasar tersebut, maka variabel yang paling banyak digunakan adalah temperatur. Banyak cara yang dilakukan untuk mengukur temperatur dengan berbagai macam elemen.

Elemen yang biasa digunakan pada pengukuran temperatur adalah thermistor, RTD, elemen IC dan thermocouple. Masing-masing elemen tersebut mempunyai karakteristik dan prinsip kerja yang berbeda. Bila dilihat dari keempat elemen tersebut, maka elemen thermistor mempunyai respon yang cepat dibandingkan dengan elemen lainnya kalau digunakan secara langsung (tanpa pelindung sarung/well). Namun kelemahannya adalah tanggapan resistansinya terhadap temperatur adalah tidak linier serta responsnya menjadi lambat jika pemilihan dan pemasangan pada shielded well tidak tepat. Untuk elemen yang lainnya seperti thermocouple merupakan elemen yang banyak digunakan di dalam industri karena jangkauan temperatur yang lebar dan bervariasi, serta relatif murah. Elemen lain, yaitu RTD (Resistance Temperature Detector) ini memang bagus, linier namun mahal; dan yang terakhir IC sensor mempunyai karakteristik yang paling linier, namun jangkauan dan penggunaannya terbatas.

Kendala pada elemen termistor adalah karakteristiknya yang tidak linear. Untuk itu karakteristik yang tidak linier tersebut perlu dilinearisasi agar mempermudah dalam pengolahan sinyalnya. Pada penelitian ini akan dilakukan linierisasi secara hardware dengan menggunakan metoda penguat inverting, untuk pembacaan dan tampilan sinyal yang dihasilkan akan digunakan sistem akuisisi data digital dengan menggunakan $\mathrm{ADC}$ dan personal computer serta LCD. 


\section{TINJAUAN PUSTAKA}

Thermistor dapat dibedakan dalam 3 jenis, yaitu thermistor yang mempunyai koefisien negatif, disebut NTC (Negative Temperature Coeficient), thermistor yang mempunyai koefisien positif, disebut PTC (Positive Temperature Coeficient) dan thermistor yang mempunyai tahanan kritis, yaitu CTR (Critical Temperature Resistance) suatu resistor yang peka terhadap panas yang biasanya mempunyai koefisien suhu negatif.

\section{Karakteristik Temperatur-Tahanan}

Gambar 1. memperlihatkan hubungan antara temperatur dengan resistansi dimana setiap bertambahnya temperatur berbanding terbalik dengan nilai resistansinya. Semakin besar temperatur yang diterima thermistor maka tahanan pada thermistornya semakin kecil. Gambar-1 memperlihatkan suatu grafik karakteristik statis suatu thermistor yang mempunyai resistansi negatif atau biasa disebut dengan NTC.

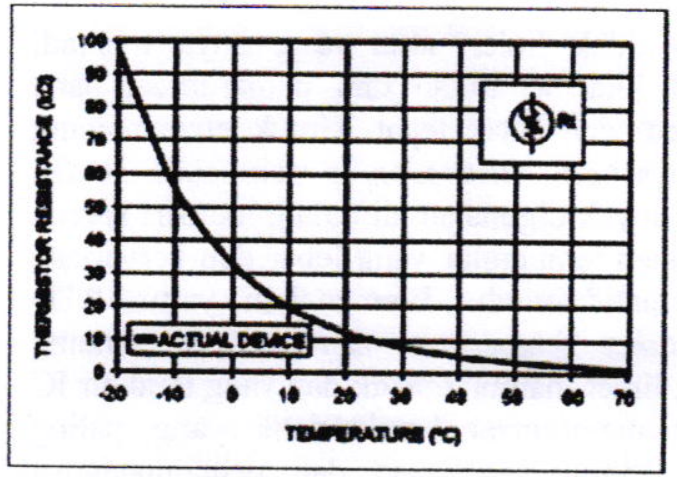

Gambar-1. Hubungan temperatur dengan resistansi dari suatu thermistor

\section{Linearitas}

Suatu sensor, idealnya mempunyai tanggapan yang linear sehingga akan memudahkan pengkondisian sinyalnya. Untuk sensor pasif, rangkaian pengkondisi sinyal tahap awal difungsikan sebagai penyedia untuk rangkaian catu daya. sedangkan untuk sensor aktif, rangkaian pengkondisi sinyal berfungsi untuk menyiapkan sinyal agar mudah dimanfaatkan selanjutnya. Sinyal hasil pengkondisian sinyal diatur untuk nilai antara 0 - $5 \mathrm{~V}$, nilai ini biasanya disesuaikan dengan masukan piranti interface (ADC) yang biasanya mempunyai masukan sebesar 0 Volt sampai dengan 5 Volt.

Salah satu karakteristik penting yang perlu diperhatikan pada pengkondisian sinyal adalah linearitas. Hubungan antara keluaran dan masukan dapat diwujudkan dalam persamaan garis lurus. Linearitas sangat diinginkan karena segala perhitungan dapat dilakukan dengan mudah jika sensor dapat diwujudkan dalam persamaan garis lurus. Kesulitan dalam pengkondisian sinyal adalah ketika tanggapan sensor tidak linear, sehingga rangkaian hardware akan menjadi semakin rumit [2].

Idealnya, pada sistem pengukuran maupun eleman-elemen yang ada di sistem pengukuran, seharusnya menghasilkan keluaran yang selalu sebanding dengan masukannya. Suatu elemen dapat dikatakan linear apabila kurva keluaran terhadap masukan membentuk garis lurus seperti yang diperlihatkan pada gambar-2.

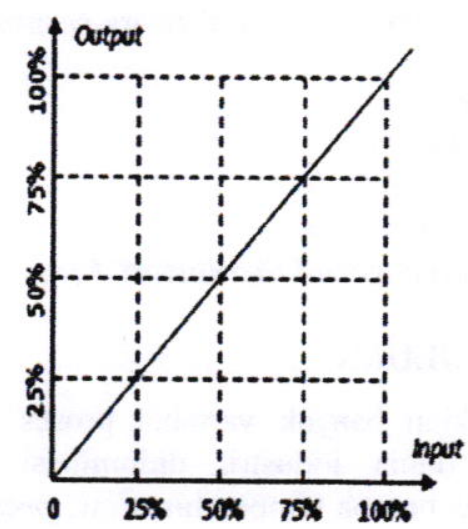

Gambar-2. Kurva linear yang ideal

Namun, bentuk linear yang ideal seperti itu sulit untuk dicapai. Biasanya, bentuk kurva tidak lurus, terkadang kurva yang dihasilkan sedikit melengkung atau berkelok-kelok. Tetapi, ketidaklurusan ini masih ada dalam batas-batas yang bisa dianggap linear. Penyimpangan dari garis linear ideal ini biasa disebut linearitas atau linearity [3].

Linierisasi suatu termistor NTC yang mempunyai resistansi $R_{T}$ dihubungkan seri dengan resistor " $\mathrm{r}$ " dan kemudian 
dikonfigurasikan dengan penguat operasi (opamp) buffer amplifier dan rangkaian penguat inverting. Gambar-3 memperlihatkan suatu rangkaian untuk melinierkan thermistor NTC (Raj. Aloke, 2012). Pada rangkaian tersebut sebagai catu untuk sensor menggunakan catu daya negatif yang kemudian diteruskan ke rangkaian buffer dan diteruskan ke rangkaian penguat inverting. Karena masukan penguat bernilai tegangan negatif, maka tegangan keluarannya akan bernilai positip yang langsung bisa diaplikasikan.

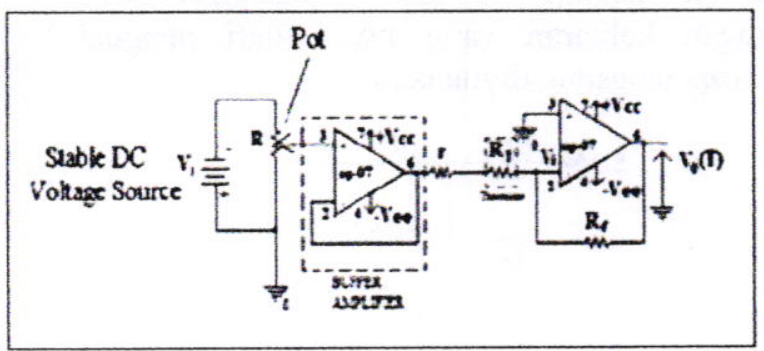

Gambar 3. Rangkaian linierisasi NTC

Tegangan keluaran sinyal untuk rangkaian pada gambar-3 ditunjukkan pada persamaan-1.

$\mathrm{V}_{\mathrm{o}}(\mathrm{T})=\frac{V i R f}{r+R_{T}}$.

Dimana:

$\mathrm{Vo}(\mathrm{T})=$ Tegangan keluaran sebagai fungsi temperatur.

$\mathrm{Vi}=$ tegangan referensi

$\mathrm{Rf} \quad=$ resistor umpan balik

$\mathrm{r}=$ resistor linierisasi

RT $=$ thermistor

Metoda linierisasi dilakukan dengan menambahkan suatu resistor " $r$ " yang dipasang secara seri dengan thermistor. Persoalan pada kasus ini adalah menentukan nilai " $r$ " sedemikian rupa sehingga error yang dihasilkan seminimal mungkin pada selang jelajah temperatur (daerah kerja yang diinginkan).

Penentuan nilai resistor " $r$ " yang optimal dilakukan dengan mendiferensialkan persaman-1 sebanyak dua kali. Hal ini mirip dengan linierisasi thermistor secara seri dengan menggunakan pembagi tegangan [5]. Dari rujukan tersebut tampak bahwa nilai " $r$ " yang mendekati nilai tengah merupakan nilai yang mempunyai rasio tegangan dengan kesalahan yang terkecil. Dengan mencari titik belok dari kurva rasio tegangan berarti akan diperoleh nilai "r" yang akan memperkecil kesalahan pengukuran. Secara matematis hal tersebut ditunjukkan pada persamaan-2 berikut ini.

$$
\frac{d^{2} V_{0}(T)}{d T^{2}}=V^{\prime \prime}{ }_{0}(\mathrm{Tm})=0
$$

$\mathrm{T}=\mathrm{Tm}$, dengan $\mathrm{Tm}$ adalah nilai titik tengah dari jangkauan pengukuran yang direncanakan. Dengan kata lain bahwa titik belok dipaksa pada nilai $\mathrm{T}=\mathrm{Tm}$. Dari persamaan-1 jelas bahwa nilai $\mathrm{Vi}$ dan $\mathrm{Rf}$ tidak berpengaruh terhadap nilai resistor linierisasi " $r$ ". Sehingga dapat kita tuliskan sebagai persamaan-3:

$\mathrm{f}^{\prime}(\mathrm{Tm})=0$

dimana :

$\mathrm{f}(\mathrm{Tm})=\frac{1}{r+R_{T m}}$

Dengan membuat turunan pertama dari persamaan-4, maka diperoleh hasil sebagaimana diperlihatkan pada persamaan-5 .

$\mathrm{f}^{\prime}(\mathrm{Tm})=-\frac{R_{T m}^{\prime}}{\left(R_{T m+} r\right)^{2}}$

Persamaan-5 ini kemudian diturunkan sekali lagi dan hasilnya ditunjukkan pada persamaan-6.

$\mathrm{f}^{\prime \prime}(\mathrm{Tm})=$

$\frac{2 R^{\prime 2} T m\left(R_{T m}+r\right)-R^{\prime \prime} T_{m}\left(R_{T m+} r\right)^{2}}{\left(R_{T m+} r\right)^{2}}$.

Untuk mendapatkan nilai $\mathrm{f}^{\prime \prime}(\mathrm{Tm})=0$ maka kondisi yang harus dipenuhi adalah :

$$
\mathrm{R}^{\prime \prime}(\mathrm{Tm})\left(R_{T m+} r\right)^{2}=2 \mathrm{R}^{\prime 2} \mathrm{Tm}\left(R_{T m+} r\right)^{2}
$$

Dan dituliskan sebagi persamaan-7 sebagai berikut:

$\mathrm{r}=\frac{2 R^{\prime 2} \mathrm{Tm}}{R^{\prime \prime} T m}-R_{T m}$

Fungsi alih untuk thermistor yang sering digunakan dan biasa disebut dengan Persamaan Beta dan diperlihatkan pada persamaan-8.

$$
R_{T}=R_{T_{0}} e^{\beta\left(\frac{1}{T}-\frac{1}{T_{0}}\right)}
$$

Dimana, 
$R_{T} \quad=$ adalah nilai tahanan $(\mathrm{Ohm})$ pada temperatur $\mathrm{T}\left({ }^{\circ} \mathrm{K}\right)$.

$R_{T_{0}}=$ adalah resistansi thermistor pada temperatur nominal $T_{0}\left({ }^{\circ} \mathrm{K}\right)$.

$\beta \quad=$ adalah konstanta (material thermistor)

Nilai resistansi pada titik tengah thermistor (Tm) dapat ditulis kembali sebagaimana diperlihatkan pada persamaan-9.

$R_{T m}=R_{T_{0}} e^{\beta\left(\frac{1}{T m}-\frac{1}{T_{0}}\right)}$

Turunan pertama dari persamaan-9 dapat dituliskan sebagaimana diperlihatkan pada persamaan-10.

$$
R_{T m}^{\prime}=R_{T m}\left(-\frac{\beta}{T_{m}^{2}}\right)
$$

Turunan kedua dari persamaan 10 akan menghasilkan persamaan-11 :

$R_{T m}^{\prime \prime}=R_{T m}\left(\frac{\beta^{2}}{T^{4}{ }_{m}}\right)+R_{T m}\left(\frac{2 \beta}{T 3_{m}}\right)$

Atau,

$R_{T m}^{\prime \prime}=R_{T m}\left(\frac{\beta}{T 3_{m}}\right)\left(2+\frac{\beta}{T_{m}}\right)$

Dengan mensubstitusikan persamaan-10 dan 11 ke dalam persamaan-7, maka diperoleh hasil sebagai berikut :

$\mathrm{r}=\frac{2 R^{2} T m}{R_{T m}\left(\frac{\beta}{T^{4} m}\right)\left(2+\frac{\beta}{T_{m}}\right)}-R_{T m}$

Dengan melalui proses penyederhanaan, maka diperoleh nilai resistor linierisasi " $r$ " sebagaimana diperlihatkan pada persamaan-12.

$$
\mathrm{r}=\mathrm{R}_{\mathrm{Tm}}\left(\frac{\beta-2 T m}{\beta+2 T m}\right)
$$

Persamaan-12 ini akan membantu untuk mendapatkan nilai resistor linierisasi " $r$ " pada jangkauan (range) pengukuran yang diinginkan.

Pada penelitian ini catu daya yang ada pada gambar-3 diganti dengan catu daya positif, sehingga keluaran dari rangkaian pada gambar-3 akan menjadi negatif, Tegangan dengan keluaran negatif ini kemudian merupakan masukan bagi rangkaian zero dan span yang mengkondisikan sinyal menjadi $0 \mathrm{~V}$ untuk masukan minimum dan akan menghasilkan 5 Volt untuk batas masukan maksimum. Gambar rangkaian zero dan span diperlihatkan pada gambar-4. Rangkaian ini merupakan penguat penjumlah inverting, sehingga keluaran dari rangkaian sensor yang negatif akan diubah menjadi positif. Dengan teknik ini tegangan keluaran dari rangkaian sensor bisa diatur sesuai dengan keinginan kita. Jadi hal ini berbeda dengan yang dilakukan pada rujukan [4] yang menggunakan tegangan negatif sebagai masukannya dan tegangan keluaran yang positi dari penguat inverting langsung digunakan.

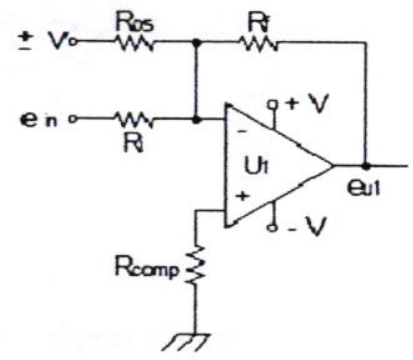

Gambar 4 Rangkaian zero dan span

Kelemahan dari rangkaian tersebut adalah bahwa tegangan keluaran yang ada akan bernilai tertentu saja (tidak leluasa untuk diatur).

\section{PERANCANGAN ALAT}

Dalam penelitian ini untuk aplikasi water heater contohnya untuk keperluan mandi, ditentukan batas pengukuran temperatur air adalah dari $15^{\circ} \mathrm{C}$ sampai dengan $75^{\circ} \mathrm{C}$. Thermistor yang digunakan mempunyai spesifikasi sebagai berikut : nilai Ro $=10 \mathrm{k}$ Ohm dengan nilai $\beta=3950{ }^{\circ} \mathrm{K}$. Tegangan masukan (referensi) untuk thermistor sebesar 1 Volt positif, Nilai resistansi umpan balik untuk rangkaian sensor sebesar $22 \mathrm{k}$ Ohm.

Pertama kali akan dihitung nilai resistor linierisasi " $r$ " dengan menggunakan persamaan12. Untuk itu akan ditentukan terlebih dahulu nilai temperatur titik tengah pengukuran $\mathrm{Tm}$, yaitu $(15+75) / 2=45^{\circ} \mathrm{C}$, atau sebesar $318^{\circ} \mathrm{K}$. Dengan menggunakan Persamaan Beta untuk thermistor, maka nilai $\mathrm{R}_{\mathrm{Tm}}$ dapat dicari sebagai berikut :

$$
\mathrm{R}_{\mathrm{Tm}}=R_{O} \cdot e^{\beta}\left(\frac{1}{T_{m}}-\frac{1}{T_{o}}\right)
$$




$$
\begin{aligned}
& =10 k \Omega\left[e^{3950}\left(\frac{1}{318}-\frac{1}{298}\right)\right] \\
\mathrm{R}_{\mathrm{Tm}} & =4345 \Omega
\end{aligned}
$$

Selanjutnya dihitung nilai $\mathrm{r}$, yaitu :

$$
\begin{aligned}
\mathrm{r} & =R_{T_{m}} \cdot\left(\frac{\beta-2 T_{m}}{\beta+2 T_{m}}\right) \\
& =4345 \cdot\left(\frac{3950-(2 \times 318)}{3950+(2 \times 318)}\right) \\
\mathrm{r} & =3140 \mathrm{Ohm}
\end{aligned}
$$

Pada aplikasinya nilai " $\mathrm{r}$ " dibuat dengan menggunakan potensio putar (multiturn) yang diatur pada nilai tersebut. Untuk menguji rangkaian bisa digunakan tahanan variabel sebagai pengganti thermistor. Dengan menggunakan Persamaan Beta untuk thermistor maka pada temperatur $15^{\circ} \mathrm{C}$ thermistor mempunyai resistansi sebesar $15.845 \mathrm{Ohm}$ dan pada temperatur $75^{\circ} \mathrm{C}$ mempunyai resistansi sebesar $1489 \mathrm{Ohm}$. Demikian pula untuk nilainilai resistansi thermistor pada temperatur yang berada pada interval temperatur di atas dapat dicari.

Tabel-1 Data tegangan keluaran $\mathrm{V}_{\text {outl }}$ (perhitungan)

\begin{tabular}{|r|r|r|}
\hline \multicolumn{3}{|c|}{ Vin $=\mathbf{1}$ Volt dan Rf $=22 \mathrm{k}$ Ohm } \\
$\mathbf{T}\left({ }^{\circ} \mathrm{C}\right)$ & $\mathbf{R T}$ (Ohm) & $\mathbf{V}_{\text {out1 }}$ \\
\hline 15,0 & 15.845 & 1,160 \\
\hline 17,5 & 14.081 & $-1,279$ \\
\hline 20,0 & 12.538 & $-1,405$ \\
\hline 22,5 & 11.187 & $-1,537$ \\
\hline 25,0 & 10.000 & $-1,676$ \\
\hline 27,5 & 8.956 & $-1,821$ \\
\hline 30,0 & 8.035 & $-1,971$ \\
\hline 32,5 & 7.222 & $-2,125$ \\
\hline 35,0 & 6.503 & $-2,284$ \\
\hline 37,5 & 5.865 & $-2,446$ \\
\hline 40,0 & 5.298 & $-2,610$ \\
\hline 42,5 & 4.794 & $-2,776$ \\
\hline 45,0 & 4.345 & $-2,942$ \\
\hline 47,5 & 3.943 & $-3,109$ \\
\hline 50,0 & 3.585 & $-3,275$ \\
\hline 52,5 & 3.263 & $-3,439$ \\
\hline 55,0 & 2.975 & $-3,601$ \\
\hline 57,5 & 2.716 & $-3,761$ \\
\hline 60,0 & 2.483 & $-3,917$ \\
\hline 62,5 & 2.273 & $-4,068$ \\
\hline 65,0 & 2.083 & $-4,216$ \\
\hline 67,5 & 1.912 & $-4,359$ \\
\hline 70,0 & 1.757 & $-4,497$ \\
\hline 72,5 & 1.616 & $-4,630$ \\
\hline 75,0 & 1.489 & $-4,757$ \\
\hline & & \\
\hline
\end{tabular}

Dengan demikian tegangan keluaran dari rangkaian sensor (pada gambar-3 adalah $\mathrm{Vo}(\mathrm{T})$ yang mulai sekarang kita sebut sebagai $\mathrm{V}_{\text {out }}$ ) yang merupakan penguat inverting dapat ditentukan. Strategi ini adalah untuk melihat apakah nilai resistor linierisasi " $r$ " sebesar 3140 $\mathrm{Ohm}$ mampu membuat sistem pengukuran menjadi linier atau tidak. Tabel-1 memperlihatkan data dan hasil tegangan keluaran $\mathrm{V}_{\text {outl }}$. Gambar-5 memperlihatkan kurva Tegangan keluaran $\mathrm{V}_{\text {outl }}$ terhadap temperatur.

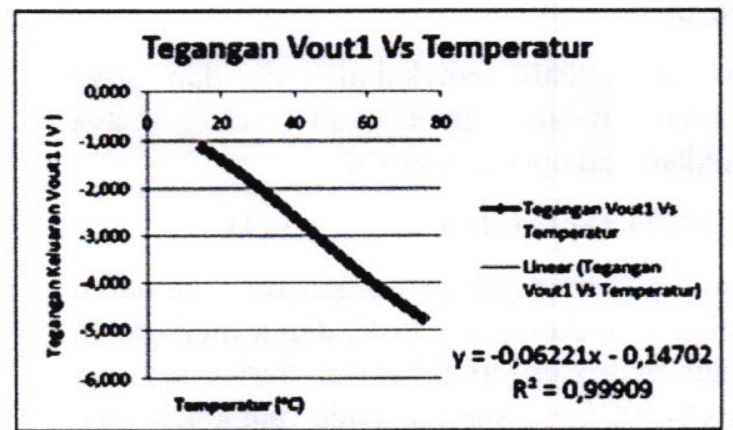

Gambar-5 Kurva hasil linierisasi (perhitungan)

Secara prinsip hubungan keluaran dan masukan tersebut dapat dinyatakan dengan persamaan-13 sebagai berikut :

$\mathrm{V}_{\text {out } 1}=-0,06221 \cdot \mathrm{T}-0,14702$.

dengan $\mathrm{V}_{\text {outl }}$ merupakan tegangan keluaran rangkaian sensor (Volt), dan $\mathrm{T}$ adalah temperatur $\left({ }^{\circ} \mathrm{C}\right)$. Tampak dari gambar-5 bahwa nilai $\mathrm{R}^{2}$ sebesar 0,99909 yang artinya bahwa sistem sudah linier. Dengan demikian pemilihan nilai " $r$ " sudah benar dan sistem menjadi linier.

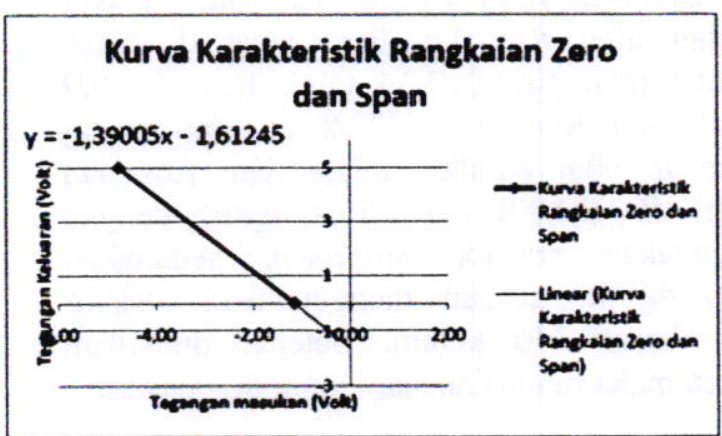

Gambar 6 Kurva karaktristik zero \& span 
Jangkauan tegangan keluaran ini kemudian akan dimasukkan ke rangkaian zero dan span dengan keluaran yang diinginkan sebesar 0 sampai dengan 5 Volt. Jangkauan tegangan sebesar 0 sampai dengan 5 Volt merupakan jangkauan untuk sinyal masukan bagi ADC dimana sinyal akan diolah dengan menggunakan perangkat digital. Secara prinsip rangkaian zero dan span yang dibangun dari rangkaian penguat penjumlah inverting harus mempunyai karakteristik sebagaimana ditunjukkan pada gambar-6.

Kurva karakteristik rangkaian zero dan span dinyatakan dalam persamaan sebagaimana ditunjukkan pada persamaan-14.

$y=-1,39005 x-1,61245$.

Dengan y merupakan tegangan keluaran rangkaian zero dan span (Volt) dan x merupakan tegangan masukan yang berasal dari rangkaian sensor (Volt). Berdasarkan pada rangkaian zero dan span seperti ditunjukkan pada gambar-4, maka tegangan keluaran rangkaian zero dan span dapat dinyatakan dengan persamaan- 15 .

$$
\mathrm{e}_{u 1}=-\frac{R f}{R i} e i n+\left(-\frac{R f}{R o s} V\right) .
$$

Jika persamaan garis pada gambar- 6 adalah $\mathrm{y}=$ $\mathrm{m} x+\mathrm{c}$, dengan nilai $\mathrm{m}$ dan $\mathrm{c}$ sebagaimana dinyatakan pada persamaan-13, maka $: \mathrm{y}=\mathrm{e}_{\mathrm{u} 1}$ dan $\mathrm{x}=$ ein. Dengan demikian diperoleh nilai $\mathrm{m}=$ $\mathrm{Rf} / \mathrm{Ri}$ dan nilai $\mathrm{c}=(\mathrm{Rf} / \mathrm{Ros}) . \mathrm{V}$.

Pada perancangan ini nilai $\mathrm{Rf}$ untuk rangkaian zero dan span dipilih sebesar $330 \mathrm{kOhm}$. Nilai V diambil dari catu daya simetris (yang positif) untuk Op-Amp yaitu sebesar 12 Volt. Dengan demikian nilai Rin dan Ros dapat dihitung. Diperoleh nilai $\mathrm{Rin}=237,2 \mathrm{k}$ Ohm; $\operatorname{Ros}=2445,9$ k Ohm dan Rcomp = 329,8 k Ohm (yang merupakan nilai parallel antara Rin, Ros dan Rcomp). Resistor Rin dan Ros dipilih dengan menggunakan resistor multiturn, sedangkan Rcomp dipilih dengan menggunakan resistor tetap sebesar $330 \mathrm{kOhm}$. Setelah dilakukan kalibrasi maka rangkaian siap untuk digunakan.

\section{SISTEM AKUISASI DATA}

Dalam penelitian ini Arduino ATMEGA328 digunakan untuk menerima sinyal masukan dari rangkaian zero dan span yang selanjutnya akan di proses dalam piranti digital.

Alasan pemilihan Arduino ATMEGA328 antara lain karena:

1. Open Source

2. Tidak memerlukan chip programmer

3. Koneksi USB

4. Fasilitas chip yang cukup lengkap

5. Ukuran kecil dan mudah dibawa

6. Bahasa pemrograman relatif mudah

7. Tersedia library gratis

8. Pengembangan aplikasi lebih mudah

9. Komunitas open source yang solid.

Arduino berfungsi sebagai analog to digital converter (ADC), data yang diterima oleh alat tersebut dapat ditampilkan pada LCD atau monitor PC.

ADC ini merupakan ADC 10 bit, sehingga ADC ini mempunyai kemampuan jelajah pencacahan sebesar $2^{10}$ atau sebesar 1024 cacahan. Jika masukan $\mathrm{ADC}$ adalah tegangan dari 0 sampai dengan 5 Volt, maka resolusi ADC ini adalah sebesar $5000 \mathrm{mV} / 1023=4,89 \mathrm{mV}$. Artinya tegangan input terkecil yang dapat dideteksi oleh ADC adalah sebesar 4,89 mV.

Fungsi atau perhitungan untuk mendapatkan kembali nilai temperatur yang dibaca sebagai besaran tegangan oleh ADC dilakukan oleh Arduino. Untuk mendapatkan nilai temperatur (T) dilakukan dengan menghitung balik melalui persamaan-14 dan persamaan-13. Dengan demikian nilai $\mathrm{T}$ dapat di peroleh kembali. Hasil pembacaan ditampilkan pada LCD dan bisa ditampikan di monitor personal computer (PC).

\section{PENGUJIAN DAN PEMBAHASAN}

Pengujian secara langsung tidak mudah dilakukan karena diperlukan suatu media yang dikendalikan temperaturnya secara konstan dan untuk membuat hal tersebut tidak mudah. Hal lain adalah bahwa thermometer pembanding 
yang dianggap standard memiliki konstanta waktu (time constant) yang tentunya berbeda dengan konstanta waktu dari alat ukur yang dibuat. Perbedaan nilai konstanta waktu ini akan memberikan hasil akhir yang berbeda manakala temperatur yang diuji berubah dengan waktu. Adanya pengaruh karakteristik dinamik ini secara simultan akan membuat pengujian menjadi lebih sulit dilakukan.

Untuk mengatasi hal tersebut, maka dilakukan pengujian dengan mengganti thermistor dengan resistor variabel yang bisa diatur dan diketahui nilainya. Artinya pengujian dilakukan dengan memperhatikan karakteristik statis saja. Walaupun sebenarnya resistor variabel yang digunakan bisa berubah resistansinya akibat temperatur lingkungan yang berubah. Namun pengaruh ini bisa diabaikan karena perubahan temperatur lingkungan dianggap sangat kecil.

Nilai resistor yang digunakan sebagai pengganti thermistor merupakan representasi dari suatu temperatur tertentu, dimana hubungan keduanya dapat diperoleh dengan menggunakan Persamaan Beta. Secara ideal nilai temperatur sebenarnya akan dapat diketahui jika nilai resistansinya diketahui.

Tabel-2 Data pengukuran tegangan keluaran $\mathrm{V}_{\text {out1 }}$

\begin{tabular}{|r|r|r|}
\hline \multicolumn{3}{|c|}{ Vin $=1$ Volt dan $R f=22 \mathrm{k}$ Ohm } \\
\hline $\mathrm{T}\left({ }^{\circ} \mathrm{C}\right)$ & $\mathrm{RT}(\mathrm{Ohm})$ & $\mathrm{V}_{\text {out } 1}$ Alat $(\mathrm{V})$ \\
\hline 17,75 & 14.457 & $-1,253$ \\
\hline 18,97 & 13.457 & $-1,329$ \\
\hline 20,33 & 12.460 & $-1,414$ \\
\hline 21,88 & 11.460 & $-1,510$ \\
\hline 23,66 & 10.465 & $-1,621$ \\
\hline 25,72 & 9.466 & $-1,749$ \\
\hline 28,14 & 8.467 & $-1,900$ \\
\hline 31,01 & 7.468 & $-2,078$ \\
\hline 34,48 & 6.469 & $-2,294$ \\
\hline 38,75 & 5.470 & $-2,560$ \\
\hline 44,11 & 4.478 & $-2,895$ \\
\hline 51,10 & 3.482 & $-3,330$ \\
\hline 60,59 & 2.483 & $-3,920$ \\
\hline 74,20 & 1.484 & $-4,765$ \\
\hline
\end{tabular}

Dengan cara demikian bias akibat keterlambatan alat ukur untuk mengejar nilai temperatur yang sebenarnya dapat dihindari; apalagi kalau temperatur air tidak bisa dijaga dengan konstan tentunya bias akan menjadi semakin besar. Tabel-2 memperlihatkan data dan hasil pengujian dari rangkaian penguat inverting yang dibuat. Semua pengukuran dilakukan secara langsung dengan menggunakan voltmeter digital yang mempunyai ketelitian 3 angka desimal di belakang koma.

Gambar-7 memperlihatkan karaktristik statis dari rangkaian penguat inverting yang diuji. Tampak dari gambar-7 bahwa persamaan yang dihasilkan oleh rangkaian penguat inverting mempunyai nilai $\mathrm{R}^{2}=1$. Hal ini memperlihatkan bahwa rangkaian penguat inverting sudah bekerja dengan baik, karena mempunyai karakteristik yang sangat linier

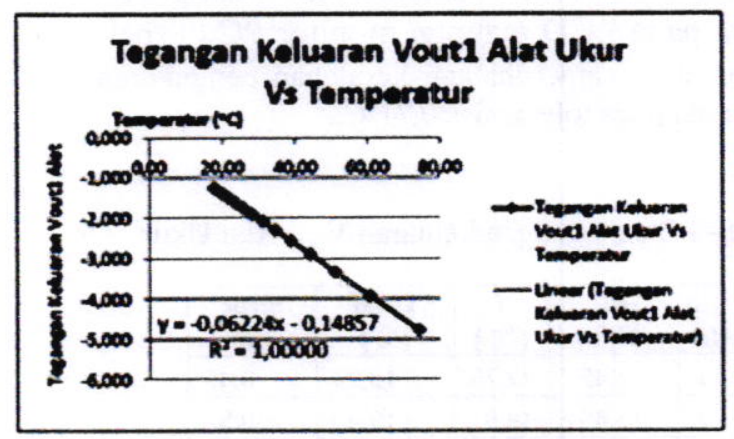

Gambar-7 Kurva hasil linierisasi penguat inverting (pengukuran)

Tabel-3 di bawah memperlihatkan data pengukuran rangkaian zero dan span yang dibuat, sedangkan gambar-8 memperlihatkan kurva karakteristik statis dari rangkaian tersebut.

Tabel-3 Data pengukuran tegangan rangkaian zero dan span

\begin{tabular}{|r|r|}
\hline$V_{\text {our1 }}$ Alat $(V)$ & $V_{\text {cur Zero \& span (V) Alat }}$ \\
\hline$-1,253$ & 0,132 \\
$-1,329$ & 0,237 \\
\hline$-1,111$ & 0,355 \\
\hline$-1,510$ & 0,490 \\
\hline$-1,621$ & 0,643 \\
\hline$-1,749$ & 0,822 \\
$-1,900$ & 1,031 \\
\hline$-2,078$ & 1,280 \\
\hline$-2,294$ & 1,580 \\
\hline$-2,560$ & 1,450 \\
\hline$-2,895$ & 2,416 \\
\hline$-3,330$ & 3,021 \\
\hline$-3,920$ & 3,845 \\
\hline$-4,765$ & 5,021 \\
\hline & \\
\hline
\end{tabular}




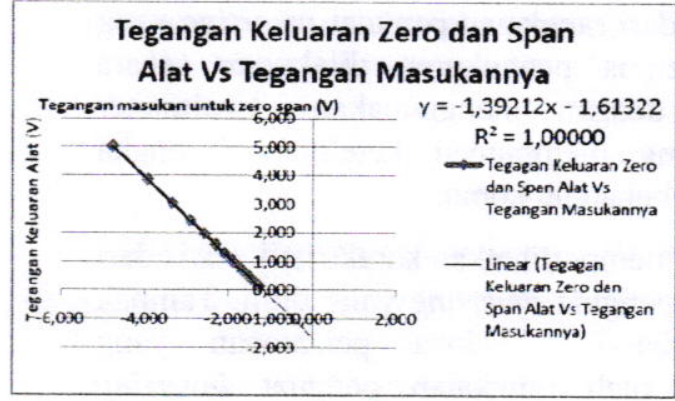

Gambar-8 Kurva karakteristik zero dan span dari alat ukur yang dibuat

Tegangan keluaran dari rangkaian zero dan span kemudian dibaca oleh Arduino dan ditampilkan hasilnya pada LCD maupun monitor PC (Tabel3). Tabel-3 memperlihatkan kesalahan pengukuran yang berada pada toleransi $\pm 0,71^{\circ} \mathrm{C}$,

Tabel-3 Data tegangan keluaran $\mathrm{V}_{\text {outl }}$ Alat Ukur

\begin{tabular}{|r|c|c|c|c|}
\hline No & $\begin{array}{c}\text { RT } \\
(\mathrm{Ohm})\end{array}$ & $\begin{array}{c}\text { T } \\
\left({ }^{\circ} \mathrm{C}\right)\end{array}$ & $\begin{array}{c}\text { T alat } \\
\left({ }^{\circ} \mathrm{C}\right)\end{array}$ & $\begin{array}{c}\text { Error } \\
\left({ }^{\circ} \mathrm{C}\right)\end{array}$ \\
\hline 1 & 14.457 & 17,75 & 18,24 & $-0,49$ \\
\hline 2 & 13.457 & 18,97 & 19,49 & $-0,52$ \\
\hline 3 & 12.460 & 20,33 & 20,79 & $-0,46$ \\
\hline 4 & 11.460 & 21,88 & 22,37 & $-0,49$ \\
\hline 5 & 10.465 & 23,66 & 24,12 & $-0,46$ \\
\hline 6 & 9.466 & 25,72 & 26,21 & $-0,49$ \\
\hline 7 & 8.467 & 28,14 & 28,58 & $-0,44$ \\
\hline 8 & 7.468 & 31,01 & 31,46 & $-0,45$ \\
\hline 9 & 6.469 & 34,48 & 35,19 & $-0,71$ \\
\hline 10 & 5.470 & 38,75 & 39,42 & $-0,67$ \\
\hline 11 & 4.478 & 44,11 & 44,79 & $-0,68$ \\
\hline 12 & 3.482 & 51,10 & 51,51 & $-0,41$ \\
\hline 13 & 2.483 & 60,59 & 60,77 & $-0,18$ \\
\hline 14 & 1.484 & 74,20 & 73,99 & 0,21 \\
\hline
\end{tabular}

Pengujian dilanjutkan dengan mengukur temperatur secara langsung pada media yang dipanaskan. Pengendalian temperatur dilakukan dengan menggunakan modul kendali pemanas tipe VVS-400 yang ada di Laboratorium Instrumentasi dan Kontrol Energi POLBAN (terbatas dari temperatur lingkungan sampai sekitar $50^{\circ} \mathrm{C}$ ). Pengujian titik-titik pengukuran lainnya diuji dengan menggunakan termos yang diatur temperaturnya secara manual.
Tabel-4 Data pengujian langsung

\begin{tabular}{|r|c|c|c|}
\hline NO & $\begin{array}{c}\text { T } \\
\left({ }^{\circ} \mathrm{C}\right)\end{array}$ & $\begin{array}{c}\text { T - ALAT } \\
\left({ }^{\circ} \mathrm{C}\right)\end{array}$ & $\begin{array}{c}\text { ERROR } \\
\left({ }^{\circ} \mathrm{C}\right)\end{array}$ \\
\hline 1 & 15,50 & 16,22 & $-0,72$ \\
\hline 2 & 16,80 & 17,28 & $-0,48$ \\
\hline 3 & 19,10 & 19,29 & $-0,19$ \\
\hline 4 & 20,60 & 20,46 & 0,14 \\
\hline 5 & 22,60 & 22,40 & 0,20 \\
\hline 6 & 24,49 & 23,92 & 0,57 \\
\hline 7 & 27,64 & 27,04 & 0,60 \\
\hline 8 & 28,82 & 28,21 & 0,61 \\
\hline 9 & 30,24 & 29,83 & 0,41 \\
\hline 10 & 31,74 & 31,28 & 0,46 \\
\hline 11 & 34,44 & 34,13 & 0,31 \\
\hline 12 & 36,34 & 36,30 & 0,04 \\
\hline 13 & 39,03 & 39,37 & $-0,34$ \\
\hline 14 & 41,41 & 41,94 & $-0,53$ \\
\hline 15 & 44,16 & 44,50 & $-0,34$ \\
\hline 16 & 48,21 & 49,00 & $-0,79$ \\
\hline 17 & 53,46 & 54,32 & $-0,86$ \\
\hline 18 & 64,50 & 65,32 & $-0,82$ \\
\hline 19 & 67,00 & 67,82 & $-0,82$ \\
\hline 20 & 72,10 & 73,06 & $-0,96$ \\
\hline
\end{tabular}

Tabel-4 memperlihatkan data pengukuran tersebut, tampak bahwa kesalahan pengukuran yang dilakukan berada pada toleransi $\pm 1^{\circ} \mathrm{C}$. Untuk pengujian yang dilakukan dengan menggunakan alat kendali otomatik, memberikan kesalahan di bawah $\pm 0,71^{\circ} \mathrm{C}$. Sedangkan pengujian yang dilakukan dengan tidak menggunakan sistem kendali temperatur otomatis (terutama di atas $50^{\circ} \mathrm{C}$ ) banyak memberikan kesalahan pada rentang antara \pm $1^{\circ} \mathrm{C}$. Hal ini terjadi karena pada temperatur yang tinggi yang diatur secara manual memberikan perubahan temperatur yang lebih cepat (akibat perbedaan dengan temperatur lingkungan yang lebih besar), sehingga sensor thermistor harus mengejar perubahan tersebut, akibatnya pengukuran menjadi tidak tepat karena temperatur uji belum tunak (steady state). Sementara itu, untuk temperatur yang lebih rendah dari temperatur lingkungan; dikarenakan perbedaannya tidak terlalu besar, maka sensor masih mampu mengejar perubahan tersebut dan menghasilkan kesalahan di sekitar nilai $\pm 0,71^{\circ} \mathrm{C}$ 


\section{KESIMPULAN}

Penentuan nilai " $\mathrm{r}$ " linierisasi sebesar 3140 berhasil membuat sistem pengukuran menjadi linier dengan menghasilkan nilai $\mathrm{R}^{2}=0,99909$. Alat ukur temperatur mampu memberikan hasil pengukuran dengan tingkat kesalahan \pm $1^{\circ} \mathrm{C}$.

\section{DAFTAR PUSTAKA}

1. Jacob, J.M., Industrial Control Electronics Application and Design, Prentice-Hall Inc, Englewood Cliffs, New Jersey, 1989.

2. Warsito, Analisis Rangkaian Pengkondis Sinyal Tahap Awal Pada Sensor Pasif: Studi
Kasus Untuk Thermistor Tipe NTC, Jurnal Sains Tek. Vol. 11 No.3 Desember 2005, FMIPA Universitas Lampung.

3. Gunterus, Frans. Falsafah Dasar Sistem Pengendalian Proses, Elex Media Komputindo, 1987.

4. R.S. Aloke, Linearization of NTC Thermistor Characteristic Using OP-AMP Based Inverting Amplifier, Thesis Master of Electrical Engineering, Jadavpur University, 2012

5. Wahyu, B.M.; Analisis Pengkondisi Sinyal Untuk Sensor Thermistor : Studi Kasus Linierisasi Secara Seri; Jurnal Teknik Energi Vol 4 N0. 2 Oktober 2014 